JSPG: Journal of Social Politics and Governance

Vol.3 No.1 Juni 2021

\section{Inovasi Tata Kelola Badan Usaha Milik Desa Pendowo Mulyo}

\author{
Nabiila Rizqi Khasanah* \\ Program Studi Ilmu Pemerintahan, \\ Universitas AMIKOM Yogyakarta. \\ * Korespondensi Penulis. Email: \\ Nabiilarizqi11@gmail.com
}

\begin{abstract}
Abstrak
BUMDes badan usaha yang seluruh atau sebagian besar modalnya dimiliki oleh Desa melalui penyertaan secara langsung yang berasal dari kekayaan Desa, digabungkan dengan pemberdayaan masyarakat didalamnya. Penelitian ini menggunakan metode kualitatif dimana peneliti menganalisis subjek berdasar sumber data yang ada dengan mewawancara penanggungjawab BUMDes Pendowo Mulyo kemudian review data tersebut dianalisis sesuai data yang diperoleh, dengan tujuan menjabarkan hasil dari inovasi BUMDES Pendowo Mulyo di desa pendowoharjo. BUMDes Pendowo Mulyo yang berdiri sejak tahun 2017 yang mana terfokus pada persewan gedung dikelurahan, namun ada juga beberapa inovasi lain pada BUMDes Pendowo Mulyo seperti pengelolaan sampah, catering, multimedia, dan konveksi (kaos).
\end{abstract}

Kata kunci : Sociopreneurship, Usaha Mikro Kecil Menengah, pemberdayaan masyarakat.

\section{Pendowo Mulyo Village Owned Enterprise Governance Innovation}

\begin{abstract}
BUMDes a business entity whose entire or most of its capital is owned by the Village through direct participation from the wealth of the Village, combined with community empowerment therein. This study uses a qualitative method in which the researcher analyzes the subject based on existing data sources by interviewing the responsible BUMDes Pendowo Mulyo then reviews the data analyzed according to the data obtained, with the aim of describing the results of BUMDES Pendowo Mulyo innovations in the pendowoharjo village.
\end{abstract}

BUMDes Pendowo Mulyo which was established in 2017 which focuses on building buildings in the village, but there are also several other innovations in BUMDes Pendowo Mulyo such as: Waste management, Catering, Multimedia, and Convection (t-shirts).

Keywords: BUMDes, Innovation, community empowerment 
JSPG: Journal of Social Politics and Governance Vol.3 No.1 Juni 2021

\section{A. PENDAHULUAN}

Menurut Undang-Undang Desa No.6 tahun 2014, definisi dari desa adalah suatu kesatuan masyarakat hukum yang memiliki batasan wilayah, yang berwenang dalam mengatur urusan pemerintah dengan kepentingan masyarakat setempat berdasar aturan bersama dengan masyarakat hak, asal-ususl/hak tradisional yang diakui dan dihormati dalam sistem pemerintahan. Pertumbuhan dan perkembangan desa sangat diperlukan dalam aspek ini, penguatan inovasi dan pengembangan suatu aspek yang menonjol guna membangun desa yang maju. Desa yang telah berkembang, juga sangat perlu perlindungan dan pemberdayaan sehingga terbentuk desa yang kuat, desa maju, desa mandiri, desa demokratis (Ridlwan, 2015). Keempat aspek tersebut tentunya diharapkan sebagai suatu landasan yang memperkuat suatu desa yang berisikan masyarakat adil makmur dan sejahtera (Wibowo, 2018). Dalam proses pembangunan dan pengembangan aspek ekonomi desa diatur dalam badan usaha yang dimiliki desa, biasanya disebut BUMDes atau badan usaha milik desa. BUMDes merupakan peraturan yang dibentuk oleh pemerintah dimaksud untuk menekan aspek kemandirian pada desa. Yang dimaksud dengan kemandirian adalah kegiatan yang dilakukan pemerintah desa dan masyarakat agar dapat memenuhi kebutuhan desa dengan kemampuan sendiri. Dengan adanya BUMDes ini diharapkan desa bisa lebih mandiri dengan mengembangkan kemampuan yang dimiliki mayarakat. Selain itu, dapat juga dikembangkan dengan memberikan inovasi yang unik dengan ciri khas sendiri. Hal ini dikarenakan BUMDes sendiri memang memiliki syarat dimana modal dan kekuatan dari usaha itu berasal dari kekayaan desa itu sendiri.
Lebih lanjut, kehidupan di wilayah DIY sendiri sebagian besar masih kawasan pedesaan. Indeks pembangunan manusia di DIY masih sedikit relatif rendah, seperti pada Kabupaten Bantul (75,58), kulonprogo $(75,33)$, Gunungkidul $(71,11)$. Oleh karena itu, penelitian ini bertujuan untuk meningkatkan upaya inovasi atau usaha apa saja yang bisa atau mungkin sudah dikelola di pedesaan dengan menggunakan fungsi BUMDes untuk meningkatkan kesejahteraan desa. Dan pada penelitian ini mengambil contoh pada desa Pendowoharjo, kabupaten Bantul, kecamatan Sewon.

BUMDes Pendowo Mulyo yang berdiri sejak tahun 2017 yang berisikan 5 usaha yang mana fokus utamanya pada persewaan gedung di kelurahan desa pendowoharjo, dan yang 5 usaha lain masih bersifat freelance bagi para pegawainya yang mana nanti pada keuntungannya disistem bagi hasil. Dengan sudah adanya beberapa inovasi dan usaha yang sudah disahkan pemerintah desa pendowoharjo diharapkan dapat mengangkat perekonomian masyarakat setempat dan bisa mengembangkan daya tari desa pendoowoharjo.

Pentingnya BUMDes bagi desa adalah 1) desa dapat mendirikan BUMDes sesuai denngan apa kebutuhan dan potensi yang dimiliki desa, 2) BUMDes berpedoman pada peraturan perundang-undangan, 3) BUMDes dapat melakukan pinjaman sesuai pada peraturan perundang-undangan (Herawati, 2016). Selanjutnya, pada UU No.6 tahun 2014 pasal 88 berbunyi pengembangan usaha, serta pembangunan desa, pemberdayaan masyarakat, dan pemberian bantuan untuk masyarakat miskin melalui bantuan sosial, hibah dan kegiatan dana yang ditetapkan dalam anggaran pendapatadan dan belanja desa (APBDes). 
JSPG: Journal of Social Politics and Governance Vol.3 No.1 Juni 2021

Meskipun demikian, BUMDes paling sering terkendala dengan modal awal dikarenakan kadang melihat kondisi desa dimana pasti mendahulukan yang kepentingan warganya. Diharapkan dengan ada BUMDes di desa pendowoharjo bisa lebih mengopyimalkan kondisi perekonomian desa, terutama untuk menciptakan lapngan pekerjaan baru, dan bisa menghasilkan barang jasa distribusi dari daerah sendiri. Selain itu, BUMDes dapat berdiri sebagai agen dari pembangunan daerah dan menjadi dorongan untuk terciptanya sektor korporasi di pedesaan dengan biaya produksi dan pengelolaan yang tidak begitu tinggi. Tujuan dari berdirinya BUMDes sendiri untuk meningkatkan ekonomi pedesaan, memaksimalkan aset yang ada didesa supaya lebih bermanfaat dalam pengelolaan ekonomi desa, kemudian meningkatkan usaha yang dimiliki masyarakat untuk mengembangkan potensi desa, pengembangan rencana dan usaha kerja anta desa dengan pihak luar, menciptkan peluang kerja bagi masyarakat, dan meningkatkan kesejahteraan masyarakat dengan memperbaiki pelyanan umum serta pemerataan ekonomi desa (Rohman, 2018). Pada peraturan desa pendowoharjo No 5 tahun 2016 mengenai pendapatan BUMDes, yakni 1) yasil usaha merupakan pendapatan BUMDes yang diperoleh dari hasil transaksi dikurangi dengan pengeluaran biaya dan kewajiban pada pihak lain serta penyusutan atas barangbarang inventaris dalam 1 (satu) tahun buku; 2) Pembagian hasil usaha BUMDesa sebagaimana dimaksud pada ayat 1 ditetapkan berdasarkan ketentuan penambahan modal BUMDesa, bagi hasil usaha kepada pemilik modal, tunjangan prestasi bagi pengurus dan karyawan, dana/bantuan sosial; 3) Alokasi pembagian hasil usaha sebagaimana dimaksud pada ayat 1 dapat dikelola melalui sistem akuntansi sederhana. Tata cara, besaran dan ketentuan lain yang mengatur tentang hasil usaha sebagaimana yang dimaksud pada ayat 1 selanjutnya diatur dalam Anggaran Dasar.

\section{B. TEORI (Literature Review)}

Proses pengembangan inovasi di area pedesaan dengan melihat peluang dari 5 usaha pada BUMDes Pendowo Mulyo gunanya untuk pengembangan desa dan pengembangan BUMDes yang mana diamanatkan dalam UndangUndang Desa. Desa pendowoharjo merupakan salah satu desa di Kecamatan Sewon, Kabuaten Bantul, Provinsi DIY. Berbagai potensi usaha banyak sekali di desa ini. Dengan adanya keberadaan BUMDes ini bisa membawa perubahan ekonomi sosial dan memberi pengaruh yang signifikan pada pendapatan asli desa (Agunggunanto dkk, 2016). Adapun keuntungan bersih dari BUMDes, dananya akan dialokasikan ke desa. Berdasarkan hasil wawancara dan hasil review diatas membuktikan bahwa BUMDes Pendowo Mulyo pergerakannya masih dibilang baru, dan alokasi keuntungannya baru bisa mencakup desa sebanyak $40 \%$ dan bagi sumber daya manusia sekitar 60\%. Untuk penggunaan fasilitas untung saja sudah beberapa terpenuhi dikarenakan sebagian besar pegawai freelancenya memiliki relasi dengan beberapa masyarakat, sehingga bisa saling membantu. Permaslahan yang paling utama adalah pada sumber daya manusia yang masih sangat kurang. Selain itu komunikasi dan sosialisasi dengan masyarakat sangat perlu ditingkatkan lagi dikarenakan masih banyak masyarakat yang belum tau mengenai keberadaan BUMDes 
JSPG: Journal of Social Politics and Governance Vol.3 No.1 Juni 2021

Pendowo Mulyo. Hal ini sedikit membuat akuntabilitas dan transparansi muncul pada pengelolaan BUMDes. Dengan adanya lembaga ekonomi desa seperti BUMDes dan Pengembangan Usaha Ekonomi Pedesaan (PUAP) diharapkan dapat mengembangkan beberapa usaha kecil atau usaha rumahan menjadi usaha sosial yang tergolong besar dan bisa menjadi fokus pengembangan pada desa tersebut.

Teori Resource Based View (RBV) untuk mewujudkan desa yang mandiri dimana perlu ada sumber daya yang berasal dari desa tersebut, dan juga unit usaha pada desa tersebut harus memiliki keunggulan masing-masing. Pengembangan konsep RBV menjadikan perspektif yang menjelaskan bahwa keunggulan bersaing berkelanjutan bersumber pada kekuatan internal yang dimiliki perusahaan itu sendiri. Secara garis besar, resource based view menyatakan bahwa sumber keunggulan bersaing berkelanjutan perusahaan adalah sumberdaya yang bernilai, langka, tidak dapat ditiru, dan tidak ada substitusinya. Sumberdaya yang dimaksud meliputi semua aset, kapabilitas, proses organisasional, karakteristik perusahaan, informasi, pengetahuan dan sebagainya yang mana sumberdaya ini berada dalam kendali perusahaan untuk implementasi strategi agar tercapai keefektifan dan efisiensi. Secara garis besar, berbagai sumberdaya tersebut dikelompokan menjadi tiga kategori yaitu sumberdaya modal sosial, sumberdaya modal manusia, dan sumberdaya modal finansial (de Massis dkk, 2013). Beberapa sumberdaya mungkin memiliki pengaruh terhadap proses implementasi strategi yang bernilai, namun beberapa sumberdaya juga
E-ISSN 2685-8096 || P-ISSN 2686-0279

mungkin tidak memberikan pengaruh yang positif terhadap implementasi strategi.

\section{METODE}

Penelitian ini menggunakan metode kuatlitatif dengan melihat kasus pada inovasi Badan Usaha Milik Desa "Pendowo Mulyo" di Desa Pendowoharjo. Wawancara dan sedikit observasi sebagai penunjang utama dalam meneliti permasalahan terutama untuk pengembangan konteks inovasi pada BUMDes Pendowo Mulyo. Wawancara digunakan untuk memenuhi data penelitian dengan bertanya langsung BUMDes Pendowo Mulyo Desa Pendowoharjo. Selain itu, terdapat observasi yang digunakan untuk memperjelas data dengan survey lapangan dan mengambil dokumentasi untuk bukti penelitian.

Adapun, data diambil dengan cara wawancara dan observasi, denga mengolah data dengan menghitung presentase dari warga dan presentase usaha yang ada di BUMDes. Data langsung dari pengurus Badan Usaha Milik Desa "Pendowo Mulyo" di Desa Pendowoharjo, sekaligus melihat peran aktif masyarakat pada usaha di BUMDes Pendowo Mulyo tersebut.

Teknis analisis data dilakukan dengan cara penetapan data dari peneliti, peneliti kemudian turun lapangan untuk mewawancarai beberapa masyarakat sebagai bahan data yang akan diolah. Selanjutnya, data diolah sesuai dengan hasil yang diperoleh.

\section{HASIL DAN PEMBAHASAN}

Berdasarkan pengembangan grafik diatas mengenai pergerakan BUMDes Pendowo Mulyo masih sangat masif, ditambah lagi pada tahun 2020 terkena dampak dengan adanya virus covid-19, mengakibatkan grafik hasilnya menurun drastis. Hasil wawancara yang saya dapat 
JSPG: Journal of Social Politics and Governance Vol.3 No.1 Juni 2021

juga menjelaskan bahwa usaha pada BUMDes ini kurang maksimal pengelolaannya. 5 usaha diatas semuanya berprogres dan juga terelaisasikan, namun memang pada tahun 2020 ini 5 usaha tersebut sangat terkena imbas akibat pandemic. Jadi dari ke limanya hanya bagian persewaan gedung karena mulai ada perkumpulan yang mempergunakan gedung desa, sehingga ada omset masuk walaupun sedikit. Untuk permodalan dan pengelolaannya masih berasal dari aset desa. Namun hasil pengelolaannya ada yang masuk ke PADes sekitar 17 juta. Dengan adanya keberadaan BUMDes ini bisa membawa perubahan ekonomi sosial dan memberi pengaruh yang signifikan pada pendapatan asli desa (PADes), dimana keuntungan bersih dari BUMDes dananya akan dialokasikan ke desa. berdasarkan

hasil wawancara dan hasil riview diatas membuktikan bahwa BUMDes Pendowo Mulyo pergerakannya masih dibilang baru, dan alokasi keuntungannya baru bisa mencakup desa sebanyak $40 \%$ dan bagi SDMnya sekitar 60\%. Untuk penggunaan fasilitas untung saja sudah beberpa terpenuhi dikarenakan sebagian besar pegawai freelancenya memiliki relasi dengan beberapa masyarakat, sehingga bisa saling membantu. Permaslahan yang paling utama adalah pada sumber daya manusia yang masih sangat kurang. Selain itu komunikasi dan sosialisasi dengan masyarakat sangat perlu ditingkatkan lagi dikarenakan masih banyak masyarakat yang belum tau mengenai keberadaan BUMDes Pendowo Mulyo. Hal ini sedikit membuat akuntabilitas dan transparansi muncul pada pengelolaan BUMDes.

Tabel 1. Matriks SWOT tata kelola BUMDes Pendowo Mulyo di desa Pendowoharjo

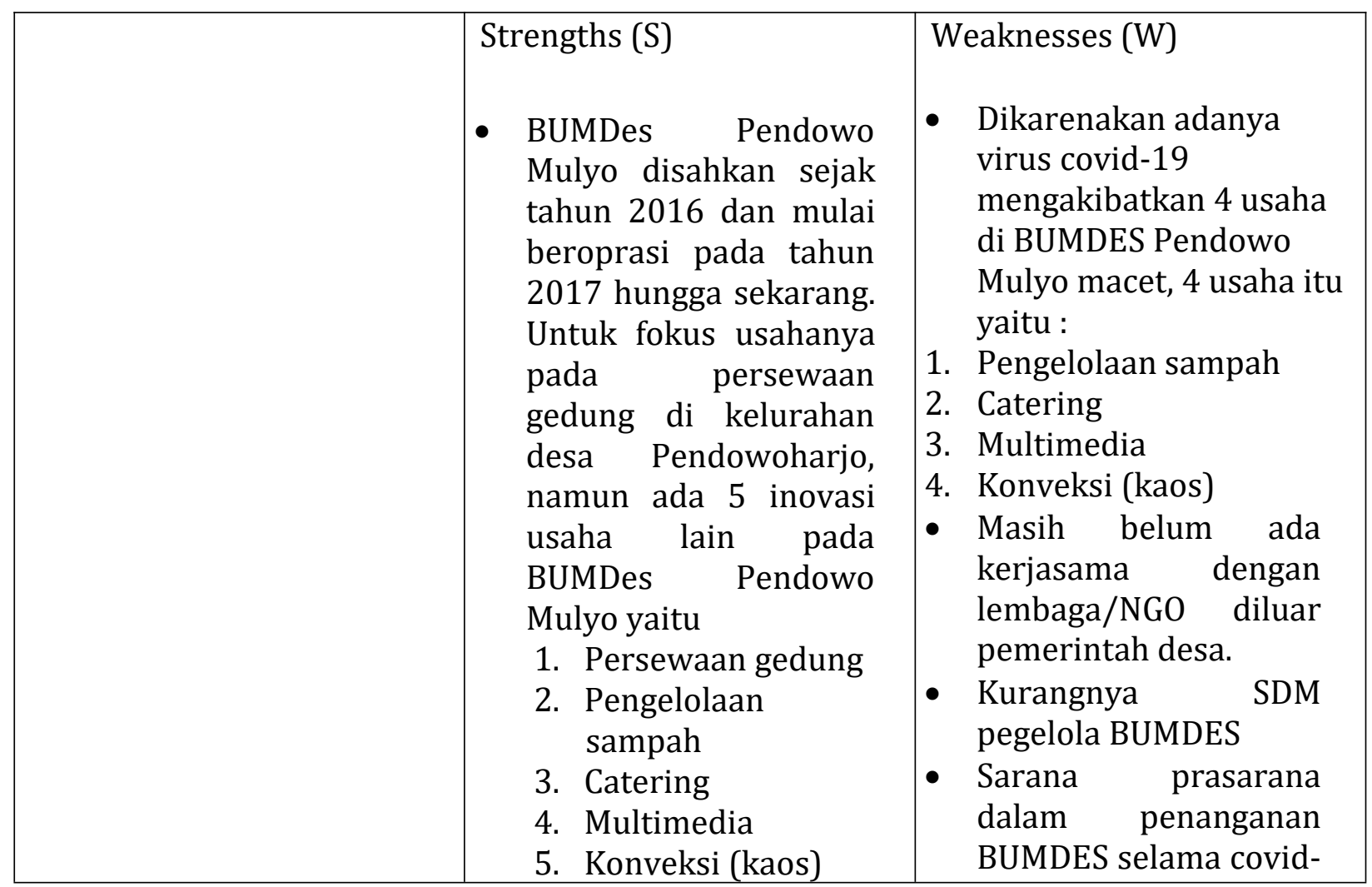




\begin{tabular}{|c|c|c|}
\hline & $\begin{array}{l}\text { - Omset tiap tahun } \\
\text { mencapai } 50 \text { juta, dana } \\
\text { yang masuk dari hasil } \\
\text { pengelolaan BUMDes } \\
\text { Pendowo Mulyo. }\end{array}$ & 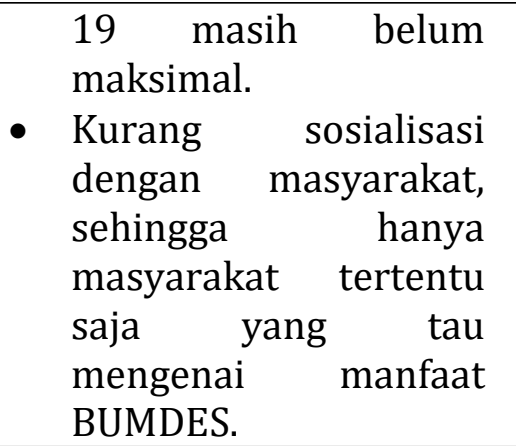 \\
\hline $\begin{array}{l}\text { Opportunuities (O) } \\
\text { - BUMDES Pendowo } \\
\text { Mulyo memiliki } 5 \text { usaha } \\
\text { yang masing-masing } \\
\text { bisa berkembang besar } \\
\text { jikalau dikelola dengan } \\
\text { maksimal } \\
\text { Bisa membantu } \\
\text { perekonomian warga } \\
\text { setempat kerjasama } \\
\text { Peluang diluar } \\
\text { dengan lembaga desa } \\
\text { pemerintah } \\
\text { banyak }\end{array}$ & $\begin{array}{l}\text { Strategi (SO) } \\
\text { - Memaksimalkan } 5 \text { usaha } \\
\text { di BUMDES Pendowo } \\
\text { Mulyo bisa membantu } \\
\text { perekonomian warga } \\
\text { sekitar, bisa } \\
\text { memberdayakan } \\
\text { masyarakat untuk } \\
\text { bekerja di BUMDES. } \\
\text { Lebih banyak } \\
\text { berinteraksi keluar } \\
\text { BUMDES, dan menjalin } \\
\text { kerjasama dengan } \\
\text { lembaga/NGO atau bisa } \\
\text { juga dengan BUMDES } \\
\text { desa lain. }\end{array}$ & $\begin{array}{l}\text { Strategi (WO) } \\
\text { - Membuat rencana plan } \\
\text { B jikalau ada kejadian } \\
\text { beberapa usaha macet } \\
\text { akibat suatu masalah, } \\
\text { tetap ada plan lain } \\
\text { untuk menjalankan } \\
\text { usaha tersebut. } \\
\text { Peningkatan sarana } \\
\text { dan prasanara yang } \\
\text { ada. }\end{array}$ \\
\hline $\begin{array}{l}\text { Threats (T) } \\
\text { - } \quad \text { Kesadaran masyarakat } \\
\text { untuk memanfaatkan } \\
\text { BUMDES masih kurang } \\
\text { - Masih kalah dalam } \\
\text { pengelolaan potensi } \\
\text { yang ada di Desa } \\
\text { Kurang bisa membackup } \\
\text { masyarakat }\end{array}$ & $\begin{array}{l}\text { Strategi (ST) } \\
\text { - Peningkatan sektor } \\
\text { dengan usaha lain untuk } \\
\text { menambah wawasan } \\
\text { pengelolaan BUMDES } \\
\text { dan menambah } \\
\text { anggaran } \\
\text { - Peningkatan SDM }\end{array}$ & $\begin{array}{l}\text { Strategi (WT) } \\
\text { - } \text { Peningkatan pendekatan } \\
\text { yang dilakukan dengan } \\
\text { masyarakat supaya } \\
\text { masyarakat dapat } \\
\text { terlibat di BUMDES }\end{array}$ \\
\hline
\end{tabular}


JSPG: Journal of Social Politics and Governance Vol.3 No.1 Juni 2021

Lebih lanjut, analisis dari matriks SWOT pada tabel 1 adalah sebagai berikut :

1. Strategi S-O (Strengths-Opportunities)

a. Memaksimalkan 5 usaha di BUMDES Pendowo Mulyo bisa membantu perekonomian warga sekitar, bisa memberdayakan masyarakat untuk bekerja di BUMDES. Memaksimalkan 5 usaha pada BUMDES Pendowo Mulyo bisa sangat berpotensi bagi desa dan masyarakat sekitar, selain untuk memajukan desa hal tersebut bisa membantu erekonoian warga, dengan cara memberdayakan masyarakat untuk berpartisipasi di dalam BUMDES.

b. Lebih banyak berinteraksi keluar BUMDES, dan menjalin kerjasama dengan lembaga/NGO atau bisa juga dengan BUMDES desa lain. Banyak berinteraksi dan berpartner dengan lembaga/NGO diluar pemerintah desa akan menjalin kerjasama yang luas terhadap BUMDES. Selain itu manfaat dengan adanya jalinan dengan lembaga pemerintah luar desa dapat berkesinambungan dengan memperluas pengelolaan usaha yang ada di BUMDES. Hal ini sangat cocok untuk BUMDES Pendowo Mulyo yang tergolong baru berdiri kisaran 3 tahunan dari 2017, supaya bisa menjalin kerjasama dengan lembaga pemerintahan diluar desa, tidak hanya dilingkup desa saja.

2. Strategi W-T (Weakness-Threats)

a. Peningkatan pendekatan yang dilakukan dengan masyarakat supaya masyarakat dapat terlibat di BUMDES. Dengan meningkatkan pendekatan dengan masyarakat ini mampu memberdayakan masyarakat sekitar, selain itu terdapat juga Karang Taruna
Pembaruan tingkat desa mereka bisa diajak bekerja sama memajukan BUMDES Pendowo Mulyo, dengan ide-ide yang fresh dan juga lebih paham terhadap teknologi masa kini karang taruna bisa menjembatani masyarakat dan pemerintah desa.

3. Strategi S-T (Strengths-Threaths)

a. Peningkatan sektor dengan usaha lain untuk menambah wawasan pengelolaan BUMDES dan menambah anggaran. Melakukan peningkatan sektor usaha, dengan mengupdate serta menambah wawasan terkait pengelolaan BUMDES, bisa bekerja sama dengan Karang Taruna Pusat dan juga lembaga pemerintahan lain. melakukan upaya promosi usaha dan juga meningkatkan sektor wisata yang menarik diarea desa, dan bisa menambah anggaran di BUMDES.

b. Peningkatan SDM. Peningkatan kualitas SDM sangat bermanfaat dalam untuk peningkatan kinerja yaitu membantu peningkatan kinerja dalam pelaksanaan program-program pengembangan pariwisata yang telah disusun. Peningkatan SDM pada BUMDES diharapkan dapat membantu untuk meningkatkan kualitas pelayanan dan kemajuan berkembangnya usaha dan juga pengembangan sektor wisata yang ada di desa Pendowoharjo.

4. Strategi W-O (Weakness-Opportunities)

a. Membuat rencana plan B jika ada kejadian beberapa usaha macet akibat suatu masalah, tetap ada plan lain untuk menjalankan usaha tersebut. Membuat rencana cadangan sangat perlu dikarenakan jikalau ada kendala terkait suatu 
JSPG: Journal of Social Politics and Governance Vol.3 No.1 Juni 2021

masalah, contohnya saat masa pandemi seperti ini usaha di BUMDES tetap berjalan, jadi tidak menimbulkan suatu kerugian walaupun omset.

b. Peningkatan sarana dan prasanara yang ada. Peningkatan sarana dan prasarana seperti dengan mengupayakan sarana dan prasaran yang diperlukan untuk peningkatan di BUMDES itu apa saja. Meningkatkan fasilitas

Lebih lanjut, hal tersebut memunculkan strategi yang digunakan untuk pengelolaan BUMDES Pendowo Mulyo, dari jangka pendek, menengah, hingga jangka panjang.

a. Strategi jangka pendek, yakni untuk strategi jangka pendek bisa dengan menghidupkan 5 usaha yang ada di BUMDES Pendowo Mulyo dengan bantuan pemerintah desa dan karang taruna pusat, supaya tujuan pada BUMDES itu cepat tercapai dan lebih hidup, berdasarkan hasil wawancara saya ternyata masih sangat sedikit masyarakat yang tau tentang BUMDES Pendowo Mulyo, maka dari itu perlu peningkatan 5 usaha yang ada didalamnya beserta pengenalan BUMDES pada masyarakat desa Pendowoharjo.

b. Strategi jangka menengah, yakni untuk strategi jangka menengahnya bisa dengan banyak belajar dalam pengembangan BUMDES, perbaiki website BUMDES dan juga medsos lainnya. Supaya hasil kinerja BUMDES bisa dipublikasi sehingga banyak lembaga lain yang tertarik. Pengelola BUMDES harus pintar dalam menjemput bola, lebih banyak mencari tau info tentang pengelolaan BUMDES dan banyak banyak mencari partner lembaga lain. c. Strategi jangka panjang, yakni banyak berpartner dengan lembaga lain, memperbarui usaha di BUMDES, memikirkan planning apa saja sekiranya muncul permasalahan dalam usaha yang ada di BUMDES, mengajak masyarakat untuk langsung andil didalam pengelolaan BUMDES, merinci target tiap tahun untuk menambah anggaran di BUMDES. Mengelola desa wisata dan potensi lain yang ada di desa..

\section{E. SIMPULAN DAN SARAN Kesimpulan}

Pembentukan BUMDes sudah dimulai dari dasar dan ditetapkan berdasarkan peraturan pemerintah desa dan disetujui lurah desa dengan menetapkan peraturan desa No. 5 tahun 2016, dan sudah tersusun berdasar anggaran dasar serta anggaran rumah tangga juga terdapat struktur organisasinya. Mekanisme penyaluran dan pemanfaatan dana berasal dari keuntungan usaha yang dibagi 60:40 \% pada akhir tahun, diserahkan kepada kepala desa atau masyarakat melalui pemerintah desa. Bentuk usaha dan pengembangan usahanya ada 5 usaha dengan fokus utama 1 usaha yaitu persewaan gedung, usaha yang dikembangkan memang terfokus pada bidang jasa, perdagangan umum dan bidang lain yang menguntungkan Untuk modal BUMDes sebagian dan seluruhnya dipisah oleh pemdes, masyarakat, dan bantuan dari pemerintah. Modal keseluruhan diambil dari kekayaan desa. Pada pengelolaan anggaran BUMDes Pendowo Mulyo sudah memuat rincian nama dan kedudukan asas, dan tujuan, kepemilikan modal, kegiatan usaha, kepengurusan dan pembagian keuntungan. Selain itu BUMDes memiliki fungsi seperti fasilitator maupun stabilisator. 
JSPG: Journal of Social Politics and Governance Vol.3 No.1 Juni 2021

Berdasarkan analisis SWOT pada BUMDES Pendowo Mulyo masih kurang dalam pengoptimalan pengelolaan usaha pada BUMDES, masih belum ada kerjasama dengan NGO diluar pemerintah desa. peningkatan sarana dan prasarana BUMDes, terutama tempat pengelolaan usaha. Kurang memberikan pembinaan ke masyarakat terkait BUMDes Pendowo Mulyo.

Saran

BUMDes agar mencari kerjasama dengan NGO/lembaga diluar pemerintah desa, serta inovasi usaha dapat diperbarui atau ditambah. Selain itu, dapat melibatkan karang taruna desa untuk membantu pengembangan BUMDes dan sosialisasi BUMDes ke masyarakat desa pendowoharjo. Peningkatan sektor dengan usaha lain untuk menambah wawasan pengelolaan BUMDES dan menambah anggaran.

\section{DAFTAR PUSTAKA}

Rohman, Abdul, dkk. (2018). Pengelolaan Administrasi Keuangan Pemerintah Desa Menuju Pengelolaan Keuangan Desa yang Tertib dan Akuntabel, Edisi Pertama. Yogyakarta: STIM YKPN.

Agunggunanto, Edy Yusuf, dkk. (2016). Pengembangan Desa Mandiri Melalui Pengelolaan Badan Usaha Milik Desa (BUMDes). Jurnal Dinamika Ekonomi dan Bisnis Vol.13 No.1

de Massis, A., Frattini, F., \& Lichtenthaler, U. (2013). Research on Technological Innovation in Family Firms: Present Debates and Future Directions. Family Business Review, 26(1), 10-31. https://doi.org/10.1177/0894486512 46625

Herawati, Erni. (2016). Badan Usaha Milik Desa, Status dan Pembentukannya. Diakses pada https://businesslaw.binus.ac.id/2016/10/16/badan- usaha-milik-desa-status-danpembentukannya/

Ridlwan, Z. (2015). Urgensi Badan Usaha Milik Desa (Bumdes) Dalam Pembangun Perekonomian Desa. Fiat Justisia, 8(3), 424-440. https://doi.org/10.25041/fiatjustisia. v8no3.314

Wibowo, Danang Ari. (2018). Perlindungan Hukum Terhadap Desa Di Indonesia. Jurnal Spirit Publik Vol 13 No 1. 